\title{
INTRAMEDULLARY SPINAL CORD METASTASES: REVIEW OF THE LITERATURE
}

\author{
Lumir Hrabalek
}

\author{
Department of Neurosurgery, Palacky University and University Hospital Olomouc \\ E-mail:lumir.hrabalek@seznam.cz
}

Received: November 2, 2009; Accepted with revision: May 17, 2010

Key words: Intramedullary/Spinal cord/Metastasis/Breast cancer/Surgery/Leptomeningeal disease

\begin{abstract}
Aims. To review the epidemiology, dissemination, clinical presentation, diagnosis, treatment, survival and functional outcome of intramedullary spinal cord metastases (ISCM).

Methods. Literature review of all surgically treated cases of ISCM and all described cases of ISCM of breast carcinoma.

Results. 42 references to 87 surgically treated cases of ISCM were found, 13 references to 27 cases with diagnosed and treated ISCM of breast carcinoma. In only 9 cases of spinal cord metastases of breast cancer was surgical resection of ISCM done (10\% of all surgically treated ISCM).

Conclusions. Three treatment modalities are available for ISCM: radiotherapy, chemotherapy, and surgery. The gold standard remains radiotherapy.

Microsurgical resection of a focal intramedullary mass appears to be feasible and should be considered in selected cases. Patients who have no evidence of widespread organ metastases or multiple intramedullary lesions and who have a life expectancy of at least a few months with tumours of non-lymphoma histology should be considered for tumor resection.

In conclusion, ISCM are difficult to treat lesions, but early diagnosis, careful surgical management and maintenance therapy may substantially contribute to a satisfactory functional outcome and prolonged survival.
\end{abstract}

\section{INTRODUCTION}

Intramedullary spinal cord metastases (ISCM) are infrenquent and clinically affect only $0.1-0.4 \%$ of all cancer patients $^{1-3}$. Most present with rapid progressive neurological deficits and require immediate examination ${ }^{1,2,4-6}$. Currently, spinal magnetic resonance imaging (MRI) is applied routinely for diagnosis ${ }^{3,7-11}$. Surgery aims at decompression of functional neural tissue and histological confirmation of tumor ${ }^{6}$. As with other central nervous system (CNS) metastases, patients with ISCM have a very short life expectancy, with a median survival of 3 to 4 months from the time of diagnosis ${ }^{3,4,12}$. I review here all surgically treated patients series in the literature.

\section{DISCUSSION AND REVIEW OF THE LITERATURE}

\section{Epidemiology}

Of all spinal tumor locations, extradural (ED) is the most common (55\%), being located primarily in the vertebral bodies and the epidural fat. Regardless of their histology, ISCM are even more rare accounting for only $0.9-5 \%$ of all spinal metastases ${ }^{1,2,13,14}$. This is particularly striking, since intracerebral metastases account for $55 \%$ of all intracranial tumors ${ }^{6}$. ISCM constitutes only $8,5 \%$ of all central nervous system (CNS) metastases ${ }^{1-3,15,16}$. Buchholz ${ }^{17}$ first described metastases in the spinal cord parenchyma in 1897 . Lung cancer (54\%) with breast car- cinoma (11\%) accounted for a majority of ISCM cases ${ }^{16}$. Physicians diagnose only $5 \%$ of these metastases before death ${ }^{18}$ however, with advanced imaging techniques like MRI, there has been recorded a progressive increase in its frequency ${ }^{3,8,9,19}$. ISCM is found together with leptomeningeal disease (LMD) in $15-55 \%$ of the cases $^{3,9,20}$.

\section{Dissemination}

Three different routes for the spread of tumors to the spinal cord have been hypothesized. Haematogeneous spread is belived to account for most $\operatorname{cases}^{1-5,9,18,21-23}$. The common coexistence of pulmonary metastasis and brain metastasis supports the idea of dissemination through the arterial route ${ }^{4,13}$. Another haematogeneous route is spread through the vertebral venous plexus (Batsonś venous plexus), extending from the pelvis to the cranial venous sinuses, and enabling retrograde transportation to the spinal cord ${ }^{1,2,13}$. The second mechanism is related to leptomeningeal dissemination by the cerebrospinal fluid. Tumor cells originating from carcinomatous meningitis may infiltrate the Virchow-Robin spaces of vessels, penetrating the spinal cord and pial membrane and invading the spinal cord parenchyma ${ }^{1,2,13,18}$. The third mechanism is direct invasion from contiguous structures. Although the dura protects the cord from invasion by malignant neoplasms ${ }^{13}$, eventual direct extension of a metastatic tumor from the spinal extradural space or CSF or nerve roots, through the dura and into the cord, and spread along perineural space to subarachnoid space and to cord parenchyma have been suggested ${ }^{17,18}$. 


\section{Clinical presentation}

In patients with ISCM, weakness was present at time of presentation in $93 \%$, sensory loss in $78 \%$ and urinogenital dysfunction in $62 \%$ of patients $3,7,8,9,13,16,24$. Brown-Sequard syndrome, defined as unilateral weakness or spasticity with contralateral loss of pain and temperature sensation was found in $23 \%$ (ref. $^{3,16}$ ). Radicular pain was seen as a presenting symptom in 24 to $33 \%$ of patients ${ }^{1,2,4,16,25}$. Rapid progression of the symptoms distinguishes ISCM from primary intramedullary tumors, which appear to typically present with a slower progression ${ }^{7,9}$. The other major differential diagnosis in the group of patients is far more common epidural spinal cord compression due to the extradural spinal metastasis ${ }^{9,18,26,27}$. ISCM patients are mostly old and neurological findings associated with myelopathy presents more acutely ${ }^{5,27,28}$. At the time of the diagnosis most ISCM patients have systemic metastases and nearly half of all ISCM cases have brain metastases ${ }^{3}$. For these reasons, the brain and spinal cord need to be screened by MRI.

\section{Diagnosis}

With the widespread use of MRI, ISCM is being encountered with increasing frequency as it was often underdiagnosed or unconfirmed before the advent of MRI ${ }^{9}$.

Gadolinium MRI has a high sensitivity in identifying such lesions. Furthermore, T2-weighted imaging demonstrates the edema related to metastasis with great success $3,10,11,16,19,20,29$. MRI with gadolinium has proven high sensitivity in the detection of intramedullary and spinal leptomeningeal neoplasms ${ }^{29,30}$. Other diagnostic tests such as plain radiographs of the spine, myelography, post-myelography computerized tomography (CT) scan, and lumbar puncture with cerebrospinal fluid (CSF) examinations have much less value in the diagnosis of ISCM $^{3,26}$. Although the CSF is frequently abnormal, with an elevated protein value, it infrequently contains malignant cells ${ }^{5,18,23}$. Grem et al. ${ }^{4}$ found malignant cells in 4 of the 22 ISCM cases (18\%) in their series. If there is a spinal LMD concomitant with ISCM, the percentage of malignant cells present in CSF is between $50 \%$ and $75 \%$ (ref. $^{3,30}$ ).

Several authors have demonstrated that PET/CT particularly with fluorine-18-fluorodeoxyglucose ( $\mathrm{F}^{18}$-FDG) enables examination of the entire spinal cord and thus permits the detection of ISCM, especially those of renal or lung origin ${ }^{31-34}$.

\section{Treatment}

Three treatment modalities are available for ISCM: radiotherapy, chemotherapy, and surgery. The gold standard remains radiotherapy, with or without steroids to reduce edema $^{1,2,4,23,35,36}$. There are some reports of long-lasting remission after irradiation, but these are limited to patients in whom a very early diagnosis was made and/or who had highly radiosensitive tumors such as small-cell carcinoma or lymphoma ${ }^{4,23,35-38}$. Treatment with steroids offered no additional survival benefit when combined with radiation therapy ${ }^{4}$.
Studies on the efficacy of chemotherapy are limited but failed to show any survival advantage ${ }^{36}$. Holoye et al ${ }^{36}$ have described tumor ablation (lung small-cell carcinoma of the lung) with cyclophosphamide, methotrexate, and lomustine, but neurological deficits and survival remained unchanged. Weissman and Grossmann recommended treatment with both intrathecal chemotherapy and radiotherapy in patients with ISCM or meningeal small-cell carcinomatosis $^{39}$

Surgery has become an alternative option in an increasing number of cases because of the increased speed and accuracy of diagnostic imaging and advances in microsurgical techniques ${ }^{5,17,27}$. Surgical resection can be performed in selected cases only and several factors are important when considering surgery $y^{5,10,11,16,22,27,38,40}$. Patient age and performance status affect the candidacy for surgical treatment. The location and severity of the primary neoplasm, as well as other metastases, weigh heavily in evaluating the prognosis, as well as anesthesia and surgical risks. Biological characteristics of the tumor itself should also be considered. Tumors that are known to be highly radioresistant should be preferentially indicated for surgical intervention. Technically, ISCM without leptomeningeal involvement is ideally suited for surgery. ISCM can be removed safely in many cases, since most ISCM are well encapsulated and some are cystic. Cystic tumors often lend themselves to surgical extirpation because the cystic component often reaches the surface of the cord and can therefore be more easily removed without disruption to normal structures ${ }^{17}$. In case of leptomeningeal involvement, radical excision is impossible. The preferred option is to limit removal to the well-defined portion of the tumor ${ }^{34}$. Dam-Hieu et al. ${ }^{34}$ reported one case of succesful surgical treatment of leptomeningeal infiltration of medullary conus and cauda equina and this review reports a second case. This case suggests the possibility of neurological improvement after surgical release of agglutinated (by leptomeningeal infiltration) nerve roots of cauda equina.

Based on surgical findings, the surgeon has to find a balance between radicality and risk for functional deterioration. Complete surgical removal of ISCM should be reserved for those cases where a clear plane of cleavage allows unproblematic microsurgical dissection of the lesion ${ }^{6}$. Histology also infleunces surgical radicality. All poorly differentiated carcinomas and all sarcomas are difficult to dissect due to the lack of a clear plain of cleavage ${ }^{6}$.

It is only within the last few years, since the development of MRI, that surgical treatment of ISCM has become a realistic treatment option. Up to January 2009 we were able to find an additional 42 references of 87 surgically treated cases of ISCM through a biomedical database search - Table 1 (ref. ${ }^{3,5,6,7,8,10,11,16,17,22,23,26,27,28,34,38,40-65}$ ).

We found 13 references to 27 cases with diagnosed and treated ISCM of breast carcinoma in the literature - Table 2 (ref. 3,11,12,17,27,34,40,42,47,55,60,66,67). We did not review autopsy diagnosed cases. In only 9 cases of spinal cord metastases of breast cancer was surgical resection of ISCM done ( $10 \%$ of all surgically treated ISCM). 
Table 1. Review of publications about surgically treated cases of ISCM.

\begin{tabular}{|c|c|c|c|}
\hline References & $\begin{array}{l}\text { Date } \\
\text { of ref. }\end{array}$ & $\begin{array}{l}\text { Surgery } \\
\text { of ISCM }\end{array}$ & Primary site of tumors (or histology) \\
\hline Silva YJ et al. ${ }^{41}$ & 1967 & 1 & colon \\
\hline Mercier P et al. ${ }^{42}$ & 1984 & 2 & breast 1 , lung 1 \\
\hline Dunne JW et al. ${ }^{8}$ & 1986 & 2 & melanoma 1 , lung 1 \\
\hline Foster OJ et al. ${ }^{43}$ & 1987 & 1 & colon \\
\hline Decker RE et al. ${ }^{27}$ & 1987 & 1 & breast \\
\hline Findlay JM et al. ${ }^{5}$ & 1987 & 2 & lung 2 \\
\hline Winkelman MD et al. ${ }^{38}$ & 1987 & 1 & thyroid gland \\
\hline Tognetti $\mathrm{F}$ et al. ${ }^{23}$ & 1988 & 4 & lung 4 \\
\hline Pelissou-Guyotat I et al. ${ }^{44}$ & 1989 & 1 & lung \\
\hline Koelman JHTM et al. ${ }^{45}$ & 1989 & 1 & lung \\
\hline Raco A et al. ${ }^{46}$ & 1992 & 1 & unknown \\
\hline Stranjalis G et al. ${ }^{11}$ & 1993 & 1 & breast \\
\hline Bizzozzero L et al. ${ }^{47}$ & 1994 & 1 & breast \\
\hline Fischer $\mathrm{G}$ et al. ${ }^{48}$ & 1994 & 4 & melanoma 2 , lung 2 \\
\hline Honma Y et al. ${ }^{49}$ & 1996 & 1 & thyroid gland \\
\hline Schiff D et al. ${ }^{3}$ & 1996 & 5 & n.a. \\
\hline Conolly ES Jr et al. ${ }^{7}$ & 1996 & 3 & lung 3 \\
\hline Sutter B et al. ${ }^{17}$ & 1998 & 3 & breast 1 , lung 2 \\
\hline$A \min R^{26}$ & 1999 & 1 & cervix \\
\hline Taniura S et al. ${ }^{50}$ & 2000 & 1 & stomach \\
\hline Isla A et al. ${ }^{40}$ & 2000 & 1 & breast \\
\hline Li Y et al. ${ }^{51}$ & 2000 & 1 & unknown \\
\hline Ateaque $\mathrm{A}$ et al. $^{52}$ & 2000 & 1 & kidney \\
\hline Mathur S et al. ${ }^{53}$ & 2000 & 1 & lymfoma \\
\hline Schijns OEMG et al. ${ }^{10}$ & 2000 & 1 & kidney \\
\hline Fakih $\mathrm{M}$ et al. ${ }^{54}$ & 2001 & 2 & kidney 2 \\
\hline Gasser TG et al. ${ }^{55}$ & 2001 & 2 & breast 1, unknown (sarcoma) 1 \\
\hline Ogino $\mathrm{M}$ et al. ${ }^{22}$ & 2002 & 1 & colon \\
\hline Kaya RA et al. ${ }^{56}$ & 2003 & 2 & colon 1 , kidney 1 \\
\hline Kalayci M et al. ${ }^{16}$ & 2004 & 1 & lung \\
\hline Aryan HE et al. ${ }^{28}$ & 2004 & 1 & lung \\
\hline Gasser T et al. ${ }^{6}$ & 2005 & 13 & $\begin{array}{l}\text { n.a. } \\
\text { (AdenoCa } 6 \text {, poorly diff Ca } 3 \text {, sarcoma } 3 \text {, small-cell Ca 1) }\end{array}$ \\
\hline De Almeida Holanda MM et al. ${ }^{57}$ & 2006 & 1 & thyroid gland \\
\hline Donovan DJ et al. ${ }^{58}$ & 2006 & 1 & kidney \\
\hline Gazzeri R et al. ${ }^{59}$ & 2006 & 1 & stomach \\
\hline Watanabe $\mathrm{M}$ et al. ${ }^{60}$ & 2006 & 2 & lung 2 \\
\hline Guppy KH et al. ${ }^{61}$ & 2006 & 1 & lung \\
\hline Sivan $\mathrm{M}$ et al. ${ }^{62}$ & 2006 & 1 & pituitary gland \\
\hline Grasso $\mathrm{G}$ et al. ${ }^{63}$ & 2007 & 1 & colon \\
\hline Marquart $\mathrm{C}$ et al. ${ }^{64}$ & 2007 & 1 & lung \\
\hline Hrabálek L et al. ${ }^{65}$ & 2008 & 1 & colon \\
\hline Dam-Hieu $\mathrm{P}$ et al. ${ }^{34}$ & 2009 & 13 & lung 8 , breast 2 , oesophagus 1 , thyroid 1 , colon 1 \\
\hline Hrabálek L & 2010 & 1 & breast \\
\hline
\end{tabular}

Date of ref:: Date of reference (year), Surgery of ISCM: Number of patients with spinal cord surgery, n.a.: not available.

Developments in imaging now allow reliable diagnosis, and advances in surgical microscopy have brought these tumors into the domain of neurosurgical care. Early suspicion of ISCM and treatment before the development of paralysis is required to improve neurologic deficit and survival of patients diagnosed with ISCM ${ }^{12}$. Radical resec- tion of an ISCM is indicated in all patients who presents with rapid progressive neurological deficits ${ }^{16}$.

\section{Survival and functional outcome}

Kalayci et al. ${ }^{16}$ reported, that improvement was seen in $66 \%$, no change in $25 \%$, and deterioration in $9 \%$ of 
Table 2. Review of publications about ISCM of breast carcinoma.

\begin{tabular}{|c|c|c|c|c|c|c|c|c|}
\hline References & $\begin{array}{l}\text { Date } \\
\text { of ref. }\end{array}$ & $\begin{array}{c}\text { Age } \\
\text { (years) }\end{array}$ & Location & Surgery & RT & ChT & Outcome & $\begin{array}{c}\text { Survival } \\
\text { (months) }\end{array}$ \\
\hline Mercier P et al. ${ }^{42}$ & 1984 & 51 & $\mathrm{~T}$ & yes & yes & no & no improvement & 2 \\
\hline Decker RE et al. ${ }^{27}$ & 1987 & 42 & $\mathrm{C}$ & yes & yes & yes & improvement & alive at 15 \\
\hline Stranjalis G et al. ${ }^{11}$ & 1993 & 47 & $\mathrm{C}$ & yes & yes & no & improvement & 24 \\
\hline Bizzozzero L et al. ${ }^{47}$ & 1994 & 52 & $\mathrm{~T}$ & yes & no & no & improvement & alive at 6 \\
\hline \multirow[t]{5}{*}{ Schiff D et al. ${ }^{3}$} & 1996 & n.a. & n.a. & n.a. & n.a. & no & n.a. & $\begin{array}{c}\text { median } 13 \\
(2-27)\end{array}$ \\
\hline & & n.a. & n.a. & n.a. & n.a. & no & n.a. & \\
\hline & & n.a. & n.a. & n.a. & n.a. & no & n.a. & \\
\hline & & n.a. & n.a. & n.a. & n.a. & no & n.a. & \\
\hline & & n.a. & n.a. & n.a. & n.a. & no & n.a. & \\
\hline Sutter B et al. ${ }^{17}$ & 1998 & 40 & $\mathrm{~T}$ & yes & yes & yes & improvement & 13 \\
\hline Isla A et al. ${ }^{40}$ & 2000 & 54 & conus & yes & yes & no & improvement & 5 \\
\hline Gasser TG et al. ${ }^{55}$ & 2001 & 45 & $\mathrm{~T}$ & yes & yes & no & improvement & alive at 6 \\
\hline Villegas AE et al. ${ }^{66}$ & 2004 & 50 & $\mathrm{~T}$ & no & yes & no & improvement & 4 \\
\hline \multirow[t]{4}{*}{ Kosmas C et al. ${ }^{67}$} & 2005 & 57 & $\mathrm{~T}$ & no & yes & no & no improvement & 1 \\
\hline & & 51 & $\mathrm{~T}$ & no & yes & yes & no improvement & 5 \\
\hline & & 42 & $\mathrm{C}, \mathrm{T}$ & no & yes & no & no improvement & 6 \\
\hline & & 47 & $\mathrm{C}$ & no & yes & no & improvement & 2 \\
\hline Watanabe $\mathrm{M}$ et al. ${ }^{60}$ & 2006 & 46 & conus & no & yes & no & n.a. & n.a. \\
\hline \multirow[t]{6}{*}{ Lee SS et al. ${ }^{12}$} & 2007 & 57 & n.a. & no & yes & no & no improvement & 3 \\
\hline & & 50 & n.a. & no & yes & no & no improvement & 5 \\
\hline & & 49 & n.a. & no & yes & no & no improvement & 9 \\
\hline & & 62 & n.a. & no & yes & no & no improvement & alive at 5 \\
\hline & & 32 & n.a. & no & yes & no & no improvement & 3 \\
\hline & & 59 & n.a. & no & yes & no & no improvement & 4 \\
\hline \multirow[t]{3}{*}{ Dam-Hieu P et al. ${ }^{34}$} & 2009 & 39 & $\mathrm{~T}$ & yes & no & no & worsening & 2 \\
\hline & & 63 & conus & yes & yes & yes & improvement & alive at 24 \\
\hline & & 35 & conus & no & no & yes & no improvement & alive at 6 \\
\hline Hrabálek L & 2010 & 48 & conus, c.e. & yes & yes & no & improvement & 4 \\
\hline
\end{tabular}

Date of ref.: Date of reference (year), RT: Radiotherapy, ChT: Chemotherapy, Outcome: neurological status, n.a.: not available, Location: level of ISCM, C: Cervical, T: Thoracic, conus: medullary conus, c.e.: cauda equina.

all cases ISCM after treatment. In patients treated with a conservative regiment, $50 \%$ improved, $28 \%$ showed no change, and $22 \%$ deteriorated. In patients with surgical resection improvement was seen in $77 \%$, and no change was seen in $23 \%$ of cases. Deterioration was not reported in his group ${ }^{16}$. The survey is nearly twice longer in surgical resection group compared to conservatively treated patients ${ }^{16}$. Histological type and grade of the tumor represented a major determinant of patient survival. Patients with intramedullary poorly differentiated carcinomas survived shortest, patients with adenocarcinomas longest $^{68,69,70}$. Patients with lung cancer showed worse prognosis than those with breast cancer, with median survival 1.0 month vs. 5.5 months $^{12}$. Interestingly, survival time was independent of CSF findings. Thus, carcinomatous meningitis is not always negative predictive factor for survival ${ }^{6}$.

Despite of recent improvements, ISCM has an poor prognosis. After the appearance of the first symptom, mortality rate in 3-4 months is $80 \%$ of cases $^{4,10,16,47,71}$.

\section{CONCLUSIONS}

Three treatment modalities are available for ISCM: radiotherapy, chemotherapy, and surgery. The gold standard remains radiotherapy.

Microsurgical resection of a focal intramedullary mass appears to be feasible and should be considered in selected cases. Patients who have no evidence of widespread organ metastases or multiple intramedullary lesions and who have a life expectancy of at least a few months with tumours of non-lymphoma histology should be considered for tumor resection.

In conclusion, ISCM are difficult to treat lesions, but early diagnosis, careful surgical management and maintenance therapy may substantially contribute to a satisfactory functional outcome and prolonged survival. 


\section{REFERENCES}

1. Edelson RN, Deck MD, Posner JB. Intramedullary spinal cord metastases. Clinical and radiographic findings in nine cases. Neurology 1972; 22:1222-1231.

2. Jellinger K, Kothbauer P, Sunder-Plassmann E, Weiss R. Intramedullary spinal cord metastases. J Neurol 1979; 220:31-41.

3. Schiff $\mathrm{D}, \mathrm{O}$ 'Neill BP. Intramedullary spinal cord metastases: clinical features and treatment outcome. Neurology 1996; 47:906-912.

4. Grem JL, Burgess J, Trump DL. Clinical features and natural history of intramedullary spinal cord metastasis. Cancer 1985; 56:2305-2314

5. Findlay JM, Bernstein M, Vanderlinden RG, Resch L. Microsurgical resection of solitary intramedullary spinal cord metastases. Neurosurgery 1987; 21:911-915.

6. Gasser T, Sandalcioglu IE, El Hamalawi B, van de Nes JA, Stolke D, Wiedemayer H. Surgical treatment of intramedullary spinal cord metastases of systemic cancer: functional outcome and prognosis. J Neuro-Oncology 2005; 73:163-168.

7. Connolly ES Jr, Winfree CHJ, McCormick PC, Cruz M, Stein BM Intramedullary spinal cord metastasis: report of three cases and review of the literature. Surg Neurol 1996; 46:329-338.

8. Dunne JW, Harper CG, Pamphlett R. Intramedullary spinal cord metastases: a clinical and pathological study of nine cases. Q J Med 1986; 61:1003-1020.

9. Potti A, Abdel-Raheem M, Levitt R, Schell DA, Mehdi SA Intramedullary spinal cord metastases (ISCM) and non-small cell lung carcinoma (NSCLC): clinical patterns diagnosis and therapeutic considerations. Lung Cancer 2001; 31:319-323.

10. Schijns OEMG, Kurt E, Wessels P, Luijckx GJ, Beuls EAM. Intramedullary spinal cord metastasis as a first manifestation of a renal cell carcinoma: report of a case and review of the literature. Clin Neurol Neurosurg 2000; 120:249-254.

11. Stranjalis G, Torrens MJ. Successful removal of intramedullary spinal cord metastasis: case report. Br J Neurosurg 1993; 7:193-195.

12. Lee SS, Kim MK, Sym SJ, Kim SW, Kim WK, Kim S-B, Ahn J-H. Intramedullary spinal cord metastases: a single-institution experience. J Neurooncol 2007; 84:85-89.

13. Okamoto H, Shinkai T, Matsuno Y, Saijo N. Intradural parenchymal involvement in the spinal subarachnoid space associated with primary lung cancer. Cancer 1993; 72:2583-2588.

14. Smaltino F, Bernini FP, Santoro S. Computerized tomography in the diagnosis of intramedullary metastases. Acta Neurochir 1980; 52:299-303

15. Hashizume Y, Hirano A. Intramedullary spinal cord metastasis. Pathologic findings in five autopsy cases. Acta Neuropathol (Berl) 1983; 614:214-218.

16. Kalayci M, Cagavi F, Gül S, Yenidünya S, Acikgöz B. Intramedullary spinal cord metastases: diagnosis and treatment - an illustrated review. Acta Neurochir (Wien) 2004; 146:1347-1354.

17. Sutter B, Arthur A, Laurent J, Chadduck J, Friehs G, Clarici G, Pendl G. Treatment options and time course for intramedullary spinal cord metastasis. Report of three cases and review of the literature. Neurosurgical Focus 1998; 4(5):e3.

18. Costigan DA, Winkelman MD. Intramedullary spinal cord metastasis, a clinicopathological study of 13 cases. J Neurosurg 1985; 62:227-233

19. Fredericks RK, Elster A, Walker FO. Gadolinium-enhanced MRI A superior technique for the diagnosis of intraspinal metastases. Neurology 1989; 39:734-736.

20. Crasto S, Duca S, Davini O, Rizzo L, Pavanello IG, Avataneo T, Cirillo S, Regge D, Soffietti R. MRI diagnosis of intramedullary metastases from extra-CNS tumors. Eur Radiol 1997; 7:732-736.

21. Chason J, Walker F, Landers J. Metastatic carcinoma in the central nervous system and dorsal root ganglia. Cancer 1963; 16:781-787.

22. Ogino M, Ueda R, Nakatsukasa M, Murase I. Successful removal of solitary intramedullary spinal cord metastasis from colon cancer Clin Neurol Neurosurg 2002; 104:152-156.

23. Tognetti F, Lanzino G, Calbucci F. Metastases of the spinal cord from remote neoplasms. Surg Neurol 1988; 30:220-227.
24. Schiff D, Shaw EG, Cascino TL. Outcome after spinal irradiation for malignant epidural spinal cord compression. Ann Neurol 1995; 37:583-589.

25. Thomas AW, Simon SR, Ewans C. Intramedullary spinal cord metastases from epithelial ovarian carcinoma. Gynecol Oncol 1992; 44:195-197.

26. Amin R. Intramedullary spinal metastasis from carcinoma of the cervix. Br J Radiol 1999; 72:89-91.

27. Decker RE, Sundrani S, Citron ML, Herrschaft DS. Intramedullary spinal cord metastases. Treated by complete resection of tumor prior to radiotherapy and chemotherapy. Spine 1987; 12:393-395.

28. Aryan HE, Farin A, Nakaji P, Imbesi SG, Abshire BB. Intramedullary spinal cord metastasis of lung adenocarcinoma presenting as Brown-Sequard syndrome. Surg Neurol 2004; 61:72-76.

29. Kamholtz R, Sze G. Current imaging in spinal metastatic disease. Semin Oncol 1991; 18:158-169.

30. Schuknecht B, Huber P, Bulle B, Nadjmi M. Spinal leptomeningeal neoplastic disease Eur Neurol 1992; 32:11-16.

31. Jayasundera MV, Thompson JF, Fulham MJ. Intramedullary spinal cord metastases from carcinoma of the lung: detection by positron emission tomography. Eur J Cancer 1997; 33:508-509.

32. Komori T, Delbeke D. Leptomeningeal carcinomatosis and intramedullary spinal cord metastases from lung cancer: Detection with FDG positron emission tomography. Clin Nucl Med 2001; 26:905-907.

33. Poggi MM, Patronas N, Buttman J, Hewitt S, Fuller B. Intramedullary spinal cord metastasis from renal cell carcinoma: Detection by positron emission tomography. Clin Nucl Med 2001; 26:837-839.

34. Dam-Hieu P, Seizeur R, Mineo JF, Metges JP, Meriot P, Simon H. Retrospective study of 19 patients with intramedullary spinal cord metastasis. Clin Neurol Neurosurg 2009; 111(1):10-17.

35. Choucair AK. Myelopathies in the cancer patient: incidence, presentation, diagnosis and management. Oncology 1991; 5:25-31.

36. Holoye P, Libnoch J, Cox J, Kun L, Byharhdt R, Almaoro U, McClelland S, Chintapali K. Spinal cord metastasis in small cell carcinoma of the lung. Radiat Oncol Biol Phys 1984; 10:349-356.

37. Murphy KC, Feld R, Evans WK, Shepherd FA, Perrin R, Sima AA, Poon PY. Intramedullary spinal cord metastases from small cell carcinoma of the lung. J Clin Oncol 1983; 1:99-103.

38. Winkelman MD, Adelstein DJ, Karlins NL. Intramedullary spinal cord metastasis. Diagnostic and therapeutic considerations. Arch Neurol 1987; 44:526-531.

39. Weissman DE, Grossmann SA. Simultaneous leptomeningeal and intramedullary spinal metastases in small cell lung carcinoma. Med Pediatr Oncol 1986; 14:54-56.

40. Isla A, Paz JM, Sansivirini F, Zamora P, García Grande A, Fernandez A. Intramedullary spinal cord metastasis. A case report. J Neurosurg Sci 2000; 44:99-101.

41. Silva YJ, McSwain B. Intramedullary spinal cord metastasis: the sole clinical manifestation of an adenocarcinoma of the colon. Can J Surg 1967; 10:341-344.

42. Mercier P, Vialle M, George B, Fardoun R, Guy G. Les metastases rachidiennes intradurales des cancers viscéraux. A propos de quatre cas. Neurochirurgie 1984; 30:177-181.

43. Foster OJ, Crockard HA. Cervical syrinx associated with an intramedullary metastasis: case report. J Neurol Neurosurg Psychiatry 1987; 50:637-639.

44. Pelissou-Guyotat I, Guyotat J, SzapiroJ, Ravon R, Moreau JJ, Vida J. Métastases spinales intradurales de néoplasies viscérales. A propos de quatre cas. Revue de la littérature. Neurochirurgie 1989; 35:236-241.

45. Koelman JHTM, Visser MDE, Kuster JAM, Dreissen JJR, Valk $\mathrm{J}$, Koster PA. Intramedullary spinal cord metastasis following a slowly progressive course. J Neurol Neurosurg Psychiatry 1989; 52:1451-1452.

46. Raco A, Delfini R, Salvami M, Innocenzi G, Ciappetta P. Intramedullary mestastasis of unknown origin: case report. Neurosurg Rev 1992; 15:135-138.

47. Bizzozzero L, Ferrari M, Villa F, Fontana R, Brusamolina R, Collice M. Intramedullary spinal cord metastasis. Case report. J Neurosurg Sci 1994; 38:193-195. 
48. Fischer G, Brotchi J. Intramedullary spinal cord tumors. Report. French Society of Neurosurgery. 45th annual congress. Neurochirurgie 1994; 40 Suppl 1:1-108.

49. Honma Y, Kawakita K, Nagao S. Intramedullary spinal cord and brain metastases from thyroid carcinoma detected 11 years after initial diagnosis - case report. Neurol Med Chir 1996; 36(8):593-597.

50. Taniura $\mathrm{S}$, Tatebayashi $\mathrm{K}$, Watanabe $\mathrm{K}$, Watanabe T. Intramedullary spinal cord metastasis from gastric cancer. J Neurosurg (Spine1) 2000; 93:145-147.

51. Li Y, Takayasu M, Takali T, Yoshimoto M, Mitsui Y, Yoshida J. Intramedullary spinal cord metastasis associated with hemorrage: a case report. No Shinkei Geka 2000; 28:453-457.

52. Ateaque A, Martin JL, O 'Brien C. Intramedullary spinal cord metastases from a hypernephroma 11 years following the diagnosis and treatment of the primary lesion. Br J Neurosurg 2000 14:474-476.

53. Mathur S, Law AJJ, Hung N. Late intramedullary spinal cord metastasis in a patient with lymphoblastic lymphoma: case report. Journal of Clinical Neuroscience 2000; 7:264-268.

54. Fakih M, Schiff D, Erich R, Logan TF. Intramedullary spinal cord metastasis (ISCM) in renal cell carcinoma: a series of six cases. Ann Oncol 2001; 12:1173-1177.

55. Gasser TG, Pospiech J, Stolke D, Schwechheimer K. Spinal intramedullary metastases. Report of two cases and review of the literature. Neurosurg Rev 2001; 24:88-92.

56. Kaya RA, Dalkilic T, Ozer F, Aydin Y. Intramedullary spinal cord metastasis: a rare and devastating complication of cancer. Neurol Med Chir (Tokyo) 2003; 43:612-615.

57. De Almeida Holanda MM, de Andrade EM, da Silva JA. Intramedullary spinal cord metastasis from thyroid carcinoma: case report. Arq Neuropsiquiatr 2006; 64 (2A):338-41.

58. Donovan DJ, Freeman JH. Solitary intramedullary spinal cord tumor presenting as the initial manifestation of metastatic renal cell carcinoma: case report. Spine 2006; 31:E460-463.

59. Gazzeri R, Galarza M, Faiola A, Gazzeri G. Pure intramedullary spinal cord metastasis secondary to gastric cancer. Neurosurg Rey 2006; 29:173-177.

60. Watanabe M, Nomura T, Toh E, Sato M, Mochida J. Intramedullary spinal cord metastasis: a clinical and imaging study od seven patients. J Spinal Disord Tech 2006; 19:43-47.
61. Guppy KH, Wagner F. Metastasis to the conus medullaris: case report. Neurosurgery 2006; 59 (5):E1148.

62. Sivan M, Nandi D, Cudlip S. Intramedullary spinal metastasis (ISCM) from pituitary carcinoma. J Neurooncol 2006; 80:19-20.

63. Grasso G, Meli F, Patti R, Giambartino F, Florena AM, Iacopino DG. Intramedullary spinal cord tumor presenting as the initial manifestation of metastatic colon cancer: case report and review of the literature. Spinal Cord 2007; 45:793-796.

64. Marquart C, Weckesser M, Schueller P, Hasselblatt M, Wassmann $\mathrm{H}$, Schroder J. Intramedullary spinal cord metastasis as initial presentation of a systemic cancer-report of a rare case. Zentralbl Neurochir 2007; 68:214-216.

65. Hrabálek L, Kalita O, Ehrmann J, Srovnal J, Hajdúch M. Spinal cord metastasis of adenocarcinoma - case report. Cesk Slov Neurol N 2008; 71/104(5):583-587.

66. Villegas AE, Guthrie TH. Intramedullary spinal cord metastasis in breast cancer: clinical features, diagnosis, and therapeutic consideration. Breast J 2004; 10:532-535.

67. Kosmas C, Koumpou M, Nikolaou M, Katselis J, Soukouli G, Markoutsaki N, Kostopoulou V, Gaglia A, Mylonakis N, Karabelis A, Pestasides D. Intramedullary spinal cord metastases in breast cancer: report of four cases and review of the literature. J NeuroOncology 2005; 71:67-72.

68. Constantini S, Miller DC, Allen JC, Rorke LB, Freed D, Epstein FJ. Radical excision of intramedullary spinal cord tumors: surgical morbidity and long-term follow-up evaluation in 164 children and young adults. J Neurosurg 2000; 93:183-193.

69. Cooper PR. Outcome after operative treatment of intramedullary spinal cord tumors in adults: intermediate and long-term results in 51 patients. Neurosurgery 1989; 25:855-859.

70. Fornari M, Pluchino F, Solero CL, Giombini S, Luccarelli G, Oliveri G, Lasio G. Microsurgical treatment of intramedullary spinal cord tumors. Acta Neurochir Suppl 1988; 43:3-8.

71. Mut M, Schiff D, Shaffrey ME. Metastasis to nervous system: spinal epidural and intramedullary metastases. J Neuro-Oncology 2005; 75:43-56. 